\title{
Purification of cytotoxic enterotoxin of Aeromonas sobria by use of monoclonal antibodies
}

\author{
J. POTOMSKI, VALERIE BURKE, I. WATSON and M. GRACEY*
}

Gastroenterology and Nutrition Research Unit, Princess Margaret Children's Medical Research Foundation, and "Department of Child Health, University of Western Australia, Perth, Australia.

Summary. Cytotoxic enterotoxin of Aeromonas sobria was purified by affinity chromatography with monoclonal antibodies. The purified enterotoxin gave a single protein band in polyacrylamide gradient gel electrophoresis and its mol. wt estimated by this technique was 63000 ; it had a pI of $6 \cdot 2$. The purified enterotoxin caused fluid accumulation in rat ileal loops and in infant mice, was cytotoxic to cultured cells, was haemolytic to human erythrocytes, and was lethal to mice after intravenous injection. The relative concentrations of enterotoxic, cytotoxic and haemolytic activities were approximately the same in a culture filtrate and in purified, electrophoretically homogeneous enterotoxin. The three activities were also inactivated to the same extent after incubation for $10 \mathrm{~min}$ at $56^{\circ} \mathrm{C}$. There was no immunological crossreactivity with cholera toxin (CT) nor did antiserum to $\mathrm{CT}$ neutralise the biological effects of the toxin.

\section{Introduction}

Interest in Aeromonas spp. as enteric pathogens has led to the investigation of possible virulence factors concerned in the pathogenesis of diarrhoea. There have been several reports of haemolytic, cytotoxic and enterotoxic properties of Aeromonas spp. and of correlation between these exotoxic activities (Cumberbatch et al., 1979; Burke et al., 1981 ; Johnson and Lior, 1981). In contrast, haemolysins of Aeromonas spp. were reported to have no enterotoxic activity and to be distinct from an extracellular product of Aeromonas spp. with the properties of a cytotonic enterotoxin (Ljungh et al., 1981). More recently, purification of an aeromonas haemolysin suggests that haemolysis, cytotoxicity and enterotoxicity are properties of a single protein (Hostacka et al., 1982; Asao et al., 1984). The cloning of aeromonas enterotoxin without haemolytic or cytotoxic activity (Chakraborty et al., 1984) appears to conflict with these reports.

In this study we report the purification of a cytotoxic enterotoxin of $\boldsymbol{A}$. sobria and its biological, physiochemical and immunological properties.

\section{Materials and methods}

\section{Bacterial strains and growth conditions}

One strain of $A$. sobria (B33) and one strain of $A$. hydrophila (B337), identified by the criteria of Popoff

Received: 19 Feb. 1986; accepted 26 Jun. 1986.
(1984), were used in the study. The $A$. sobria strain was isolated from faeces of a patient with gastro-enteritis and gave positive results in the rat intestinal loop test (RIL), the suckling mouse test, the cytotoxicity test and the haemolytic assay. The $A$. hydrophila strain was obtained from H. M. Atkinson (South Australian Institute of Technology, Adelaide, Australia) and gave negative results in all these tests. Bacteria were grown in Tryptone Soya Broth (Oxoid) supplemented with yeast extract (Oxoid) $0.6 \%$ at $37^{\circ} \mathrm{C}$ and $300 \mathrm{rpm}$ in an environmental incubator shaker (New Brunswick Scientific, Edison, NJ, USA) for $22 \mathrm{~h}$. Cell-free supernates for the biological tests were made by centrifuging cultures at $2000 \mathrm{~g}$ for $10 \mathrm{~min}$ at $4^{\circ} \mathrm{C}$ and filtering through $0.45 \mu \mathrm{m}$ membrane filters (Millipore Corp., Bedford, MA, USA).

\section{Preparation of crude antigen}

The bacterial preparation was centrifuged at $4000 \mathrm{~g}$ for $30 \mathrm{~min}$ and solid ammonium sulphate was added to the supernate to $60 \%$ of saturation at $4{ }^{\circ} \mathrm{C}$. The precipitate was left at $4^{\circ} \mathrm{C}$ overnight and then was collected by centrifugation at $13500 \mathrm{~g}$ for $20 \mathrm{~min}$, and dialysed against phosphate buffered saline (PBS), $p \mathbf{H} 7 \cdot 3$.

\section{Production of monoclonal antibodies}

Female Balb/c mice (Murdoch University, Perth, Australia), 6-8 weeks old, were immunised twice with the $A$. hydrophila or $A$. sobria crude antigen. Mice were given $0 \cdot 1 \mathrm{ml}$ of crude antigen $(1 \mathrm{mg} / \mathrm{ml})$, emulsified with an equal volume of Freund's complete adjuvant, subcutaneously. The treatment was repeated 3 weeks later when crude antigen was emulsified with Freund's 
incomplete adjuvant. After 3 months, mice were given booster injections of $5 \mu \mathrm{g}$ of crude antigen in PBS intravenously 3 days before the hybridisation. Spleen cells $\left(10^{8}\right)$ from hyperimmunised mice were fused with $10^{7}$ NS-1 myeloma cells according to the method of Galfe and Milstein (1981). Culture supernates were assayed for cross-reactivity with crude antigen by enzyme-linked immunosorbent assay (ELISA). Hybridomas of interest were cloned and recloned by the limiting dilution method with mouse spleen cells as feeder layers. Ascites tumours were induced in pristane $(2,6,10,14$-tetramethylpentadecane; Sigma Chemical Co., St Louis, Mo, USA) treated Balb/c mice by intraperitoneal injection of $3 \times 10^{7}$ cloned cells. Immunosuppression was achieved with an injection of cyclophosphamide $c .0 .5 \mathrm{mg} / 20 \mathrm{~g}$ animal weight $24 \mathrm{~h}$ before cell transplantation.

\section{ELISA}

The hybridoma supernatant fluids were assayed for cross-reactivity with crude antigen ELISA. Microtitration plates (Linbro; Flow Laboratories) were coated with $100 \mu \mathrm{l}$ of $A$. sobria or $A$. hydrophila crude antigen $(200 \mu \mathrm{g} /$ $\mathrm{ml})$ in coating buffer $(0.01 \mathrm{M}$ carbonate-bicarbonate buffer, $p \mathrm{H} \mathrm{9.6)} \mathrm{and} \mathrm{incubated} \mathrm{for} 3 \mathrm{~h}$ at $37^{\circ} \mathrm{C}$ followed by at least $20 \mathrm{~h}$ at $4^{\circ} \mathrm{C}$. The plates were washed three times with PBS-Tween 20 and $100 \mu$ of hybridoma supernate diluted in PBS-Tween with fetal calf serum (FCS) $1 \%$ as added. After incubation for $2 \mathrm{~h}$ at $37^{\circ} \mathrm{C}$, the plates were washed again and $100 \mu \mathrm{l}$ of alkaline phosphatase-labelled sheep anti-mouse immunoglobulin diluted 1 in 2000 in PBSTween $-1 \%$ FCS was added. The plates were allowed to incubate at $37^{\circ} \mathrm{C}$ for $2 \mathrm{~h}$, washed and $100 \mu \mathrm{l}$ of $\mathrm{p}$ nitrophenylphosphate $1 \mathrm{mg} / \mathrm{ml}$ in diethanolamine buffer ( $p \mathrm{H} \mathrm{9.8)} \mathrm{was} \mathrm{added.} \mathrm{The} \mathrm{absorbance} \mathrm{at} 405 \mathrm{~nm}$ was read in a Multiscan reader (Flow Laboratories) after incubation for $1 \mathrm{~h}$ at $37^{\circ} \mathrm{C}$; optical densities 0.2 above background were considered positive results.

\section{Immunoadsorption}

The $\gamma$ globulin of mouse ascites fluid $(10 \mathrm{ml})$ was precipitated by adding an equal volume of cold, saturated ammonium sulphate at $4^{\circ} \mathrm{C}$. After $30 \mathrm{~min}$ at $4^{\circ} \mathrm{C}$ this preparation was centrifuged at $10000 \mathrm{~g}$ for $30 \mathrm{~min}$. The pellet was washed with $50 \%$ saturated ammonium sulphate, dissolved in one tenth of the original volume of coupling buffer $(0.1 \mathrm{M} \mathrm{NaHCO}, p \mathrm{H} 8.5$, containing $0.5 \mathrm{M}$ $\mathrm{NaCl}$ ) and dialysed against coupling buffer for $24 \mathrm{~h}$ at $4^{\circ} \mathrm{C}$. A sample containing $100 \mathrm{mg}$ of protein was coupled to $5 \mathrm{~g}$ of CNBr Sepharose 4B according to manufacturer's instructions (Pharmacia Fine Chemicals, Uppsala, Sweden) and transferred to a column (C16/20, Pharmacia); A. sobria crude antigen ( $25 \mathrm{mg}$ of protein in $12 \mathrm{ml}$ of PBS) was then run through the column. Unbound material was removed by washing with PBS. Non-specifically-bound proteins were removed by washing with $0.1 \mathrm{M}$ borate

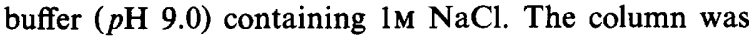
eluted with $3 \mathrm{M} \mathrm{KSCN}(p \mathrm{H} 7 \cdot 4)$. All the bound material eluted in a single peak. Fractions constituting this peak were pooled, dialysed against PBS and stored at $-70^{\circ} \mathrm{C}$. Antigens purified by immunoadsorption were designated by the number of their specific monoclonal antibody.

\section{Biological assays}

The suckling-mouse test was done as described by Burke et al. (1981); the intestinal weight/body weight (IW/BW) ratio was the sole assay criterion. All samples were diluted with PBS and an IW/BW ratio of $\geq 0.08$ was considered a positive result. Six mice were used for each test and two tests were performed on each sample. One mouse unit was defined as the minimum amount of protein that caused IW/BW ratio $\geq 0.08$.

The rat ileal loop test was carried out as described by Pierce (1977). In rats under ether anaesthesia, four segments in each rat were isolated by ties with additional ties separating consecutive loops. At least three rats were used for each test. Test solutions of PBS were injected via a 26-gauge needle in 0.25 - $\mathrm{ml}$ volumes in alternate loops so that the lower loop contained solution or PBS in alternate animals. The abdomen was sutured and the animals were killed with ether $18 \mathrm{~h}$ later. Loops were excised and weighed, then drained to measure the volume of fluid. The length of the segment, with a standard weight attached, was measured against a vertical rule. Results were expressed as $\mathrm{ml}$ of fluid per $\mathrm{cm}$ of intestine; values $>0.2 \mathrm{ml} / \mathrm{cm}$ were considered positive. One loop unit was the minimum amount of protein that produced fluid accumulation of at least $0.2 \mathrm{ml} / \mathrm{cm}$.

The cytotoxic activity of the cell-free supernate and the purified toxin was assayed in $\mathrm{Y} 1$ and $\mathrm{CHO}-\mathrm{K} 1$ cells. For titration, $25 \mu \mathrm{l}$ of doubling dilutions of the test samples of PBS were added to $100 \mu \mathrm{l}$ of cell monolayers in 96-well microculture plates (Linbro; Flow Laboratories) and incubated for $18 \mathrm{~h}$ in $\mathrm{CO}_{2} 5 \%$ at $37^{\circ} \mathrm{C}$. Visible cytotoxicity was confirmed by trypan blue dye exclusion test. Death of $>50 \%$ of $\mathrm{Y} 1$ or $\mathrm{CHO}-\mathrm{K} 1$ cells was considered a positive result. One cytotoxic unit was the minimum amount of toxin that produced a positive result in this test.

The haemolytic activity of toxin preparations was assayed with human group-O erythrocytes in 96-well microtitration plates; $100 \mu \mathrm{l}$ of doubling dilutions of the toxin solution in PBS containing bovine serum albumin $0.1 \%$ were added to $100 \mu \mathrm{l}$ of human red blood cells $1 \%$ $\mathrm{v} / \mathrm{v}$ in PBS. Haemolysis was recorded after incubation for $1 \mathrm{~h}$ at $37^{\circ} \mathrm{C}$ then $1 \mathrm{~h}$ at $4^{\circ} \mathrm{C}$. Lysis of at least $50 \%$ of the erythrocytes was considered a positive result. One haemolytic unit was the minimum amount of toxin that gave a positive result in this test.

Mouse lethal toxin activity was determined by the intravenous injection of $100 \mu \mathrm{l}$ of toxin diluted in PBS into two adult Balb/c mice for each dilution and the amount of toxin required to kill $50 \%$ of the animals (LD50) was estimated. 


\section{Polyacrylamide gradient gel electrophoresis}

The toxin was analysed by electrophoresis on slabs of $2 \cdot 5-27 \%$ concave gradient acrylamide (Gradient Laboratories, Pyrmont, Australia) in Tris-borate buffer $p \mathbf{H ~ 9 . 6}$ (Margolis and Kenrick, 1968). Gels were run in constant voltage conditions for at least $2000 \mathrm{vh}$. Proteins, including mol.-wt markers (Pharmacia), were stained with $0.1 \%$ Coomassie brilliant blue R-250 (Bio-Rad Laboratories, Richmond, CA, USA) $0.1 \%$, and destained in methanol $25 \%$ and acetic acid $10 \%$.

\section{Estimation of isoelectric point ( $p I)$}

Isoelectric focussing of the pure toxin $(15 \mu \mathrm{g})$ was performed with a LKB Ultrophor electrofocussing unit (LKB, Bromma, Sweden) and a LKB Ampholine PAG plate, $p \mathrm{H} \mathrm{3.5-9.5}$ according to manufacturer's instructions. After focussing, the $p \mathrm{H}$ gradient was measured by means of a semi-micro surface $p \mathrm{H}$ electrode (Orion Research Inc., Cambridge, MA, USA). Gels were stained with Coomassie brilliant blue R-250 $0 \cdot 12 \%$ to locate protein bands.

\section{Immunoglobulin class, subclass and light chain}

Monoclonal antibodies in growth medium from stable cell lines were concentrated 25-fold (Minicon B15, Amicon Corp., Danvers, MA, USA) and used in double immunodiffusion against specific rabbit antisera to mouse immunoglobulin $\mathbf{M}$ (IgM), IgG (7S), IgG1, IgG2a, $\operatorname{lgG} 2 \mathrm{~b}, \mathrm{IgG} 3, \kappa$ and $\lambda$ light chain (Bionetics Laboratory Products, Kensington, MD, USA).

\section{Double immunodiffusion}

Double immunodiffusion was performed in agarose $0.9 \%$ in borate saline buffer $p \mathrm{H} 8.5$ (ionic strength 0.175 ) containing polyethylene glycol $3 \%$ and thiomersal $0.01 \%$.

\section{Protein estimation}

Protein was estimated by the method of Read and Northcote (1981) with bovine serum albumin (Sigma) as the standard.

\section{Preparation of antisera}

Antiserum to cholera toxin (CT)(Calbiochem-Behring, La Jolla, CA, USA), and antiserum to $A$. sobria cytotoxic enterotoxin were produced by repeated inoculations of purified toxins into rabbits. Animals were given primary immunisation subcutaneously with Freund's complete adjuvant and two subcutaneous booster immunisations at monthly intervals with Freund's incomplete adjuvant. The doses of cholera toxin for primary and booster immunisations were 10,5 and $5 \mu \mathrm{g}$; the respective doses of $A$. sobria cytotoxic enterotoxin were 20,10 and $10 \mu \mathrm{g}$. The animals were bled 10 days after the last injection.

\section{Results}

\section{Production of monoclonal antibodies}

The fusion of NS-1 myeloma cells and $A$. sobria crude antigen-immunised mouse spleen cells resulted in hybrid colonies appearing in all the 96 wells dispensed. When tested in ELISA, 44 supernates reacted with $A$. sobria crude antigen but not with $A$. hydrophila crude antigen. The two hybrid colonies that gave the highest binding in ELISA with $A$. sobria were selected for cloning by limiting dilution. After cloning and recloning, two stable cell lines, designated $1 / 20 \mathrm{C} 11 \mathrm{G} 9$ and 4/5A8F5, producing monoclonal antibodies that reacted with $A$. sobria crude antigen, were obtained. These two monoclonal antibodies were found to be of the IgG1 and IgG2b subclasses with $\lambda$ light chains as determined by double immunodiffusion.

\section{Isolation of aeromonas cytotoxic enterotoxin}

To prepare sufficient IgG for immunoadsorbent columns, $1 / 20 \mathrm{C} 11 \mathrm{G} 9$ and 4/5 A8F5 cells were injected intraperitoneally into Balb/c mice and, when tumours had developed, ascitic fluids were collected and pooled. IgG1 and IgG2b were purified by ammonium sulphate precipitation and coupled to CNBr-activated Sepharose 4B., A. sobria crude enterotoxin was passed through these two columns and adsorbed material was eluted with $3 \mathrm{M} \mathrm{KSCN}$. Eluates derived from immunoadsorption columns were dialysed against PBS and concentrated by ultrafiltration. Ouchterlony immunodiffusion analysis showed lines of identity between $1 / 20 \mathrm{C} 11$ G9 and 4/5 A8F5 eluates with antiserum to $A$. sobria crude antigen (fig. 1). Further electrophoretic and biological analysis confirmed their identity. When eluates from immunoadsorption columns were analysed by polyacrylamide gradient gel electrophoresis only one protein band was demonstrated (fig. 2)). This band had a faster migration rate than the standard of lowest mol. wt $(67000)$. An estimation of its size by regression analysis was 63000 . The $\mathrm{pI}$ of the toxin was $6 \cdot 2(5 \cdot 4-7 \cdot 1)$.

\section{Biological activities of toxin}

The protein purified by immunoadsorption produced a positive reaction in the rat intestinal loop test, the suckling-mouse test, the cytotoxicity test and the haemolytic assay (table). The dose-response curves of the toxin in these four tests are illustrated in figs. 3,4 and 5 .

In the suckling-mouse test, IW/BW ratio was 
Table. Enterotoxic, cytotoxic and haemolytic activity in culture supernate and purified Aeromonas toxin

\begin{tabular}{|c|c|c|c|}
\hline \multirow[b]{2}{*}{ Toxin assay } & \multicolumn{2}{|c|}{ Units/mg (SEM)* in } & \multirow{2}{*}{$\begin{array}{c}\text { Activity } \\
\text { ratio } \\
\text { (pure toxin } \\
\text { supernate) }\end{array}$} \\
\hline & $\begin{array}{c}\text { culture } \\
\text { supernate }\end{array}$ & pure toxin & \\
\hline Rat intestinal loop test & $160(0)$ & $7530(190)$ & 47 \\
\hline Suckling-mouse test & $160(0)$ & $7700(101)$ & 48 \\
\hline Y1 cytotoxicity test & $2048(0)$ & $65000(8280)$ & 32 \\
\hline Haemolytic assay & $1024(0)$ & $39700(7823)$ & 39 \\
\hline
\end{tabular}

* Mean values and standard error from two to four experiments. See Methods for definition of units.

proportional to the amount of the toxin in the range $62 \cdot 5-500 \mathrm{ng}$. The minimum amount of the enterotoxin detected was $130 \mathrm{ng}$ and the maximum reaction was observed at $2 \mu \mathrm{g} / \mathrm{mouse} ; 16 \mu \mathrm{g}$ of the toxin was not lethal to the infant mice and IW/BW ratio $(0 \cdot 115 \pm 0 \cdot 005)$ was almost the same as for $500 \mathrm{ng}(0.114 \pm 0.007)$. The minimum amount of enterotoxin detected in the rat intestinal loop test was $109 \mathrm{ng}$. Higher doses of the toxin (500 ng) caused inflammation and haemorrhage.

The enterotoxin was cytotoxic to Y1 adrenal cells (65 000 units/mg) and CHO-K1 cells (fig. 6). The smallest amount of pure toxin that gave a positive response in the $\mathrm{CHO}-\mathrm{K} 1$ assay was $10 \mathrm{pg}$. The toxin was also haemolytic to human erythrocytes (39 700 units/mg).

The relative concentrations of these activities were approximately the same in bacterial culture supernate and in purified, electrophoretically homogeneous, enterotoxin (table). Heating affected enterotoxicity, cytotoxicity and haemolvsis similarly. After incubation at $56^{\circ} \mathrm{C}$ for $101 \ldots$, about $99 \%$ of its cytotoxic and haemolytic activities were

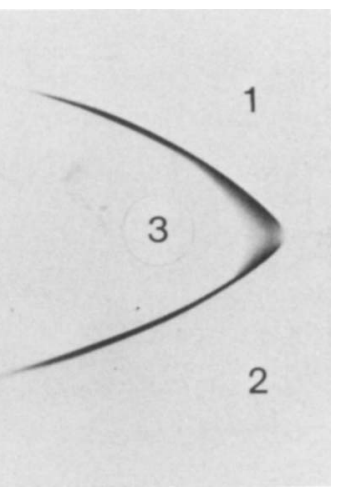

Fig. 1. Ouchterlony immunodiffusion analysis of the relationship of $1 / 20$ C11G9 (1) to $4 / 5$ A8F5 (2) eluates with antiserum to $A$. sobria crude antigen (3). lost and 8 loop and mouse units did not give positive results.

The enterotoxin was also lethal to mice (LD50 $11 \mu \mathrm{g} / \mathrm{kg}$ ) after intravenous injection. A doserelated period of survival was observed; thus the animals that received $4 \mu \mathrm{g}$ of the toxin died within

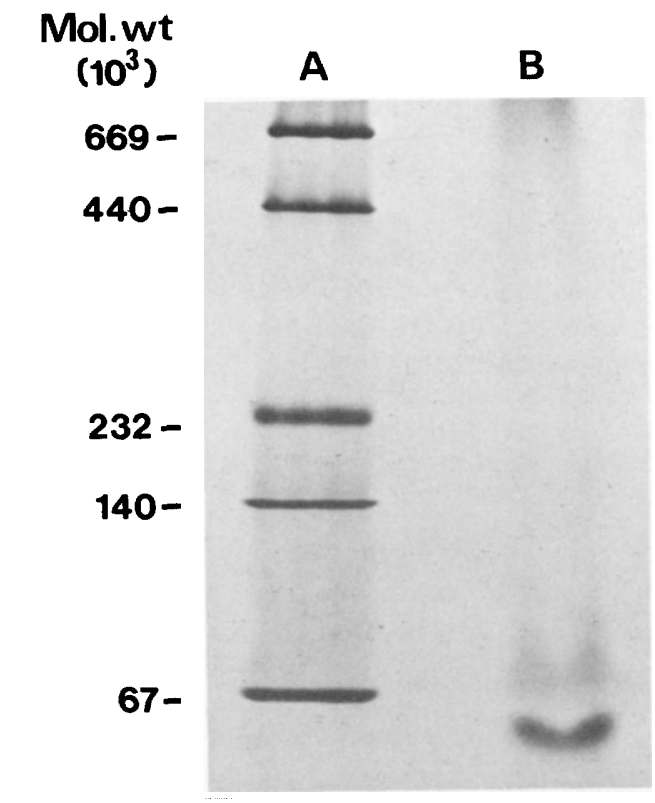

Fig. 2. Gradient gel electrophoresis of the purified toxin. A. Mol.-wt reference proteins - thyroglobulin (669 000), ferritin $(440000)$, catalase $(232000)$, lactate dehydrogenase $(140000)$ and albumin $(67000)$. B. Purified toxin $(11 \mu \mathrm{g})$.

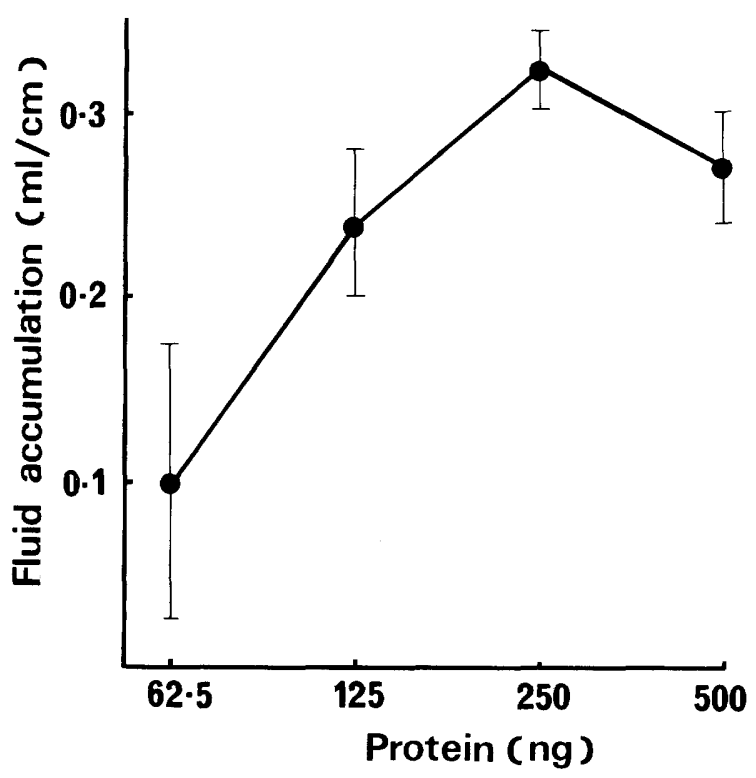

Fig. 3. Rat intestinal loop test: accumulation of fluid in response to amount of enterotoxic protein. Each point shows mean $\pm S D$ for 8 loops. 


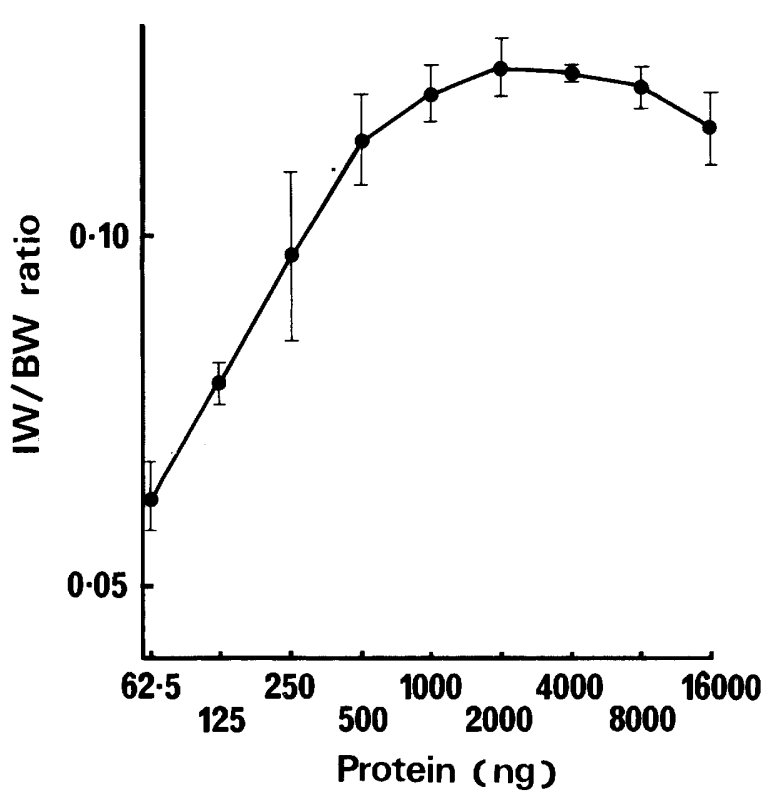

Fig. 4. Suckling-mouse assay: intestinal weight to remaining body weight ratio (IW/BW) in response to amount of enterotoxic protein. Each point represents mean $\pm S D$ for 18 mice.

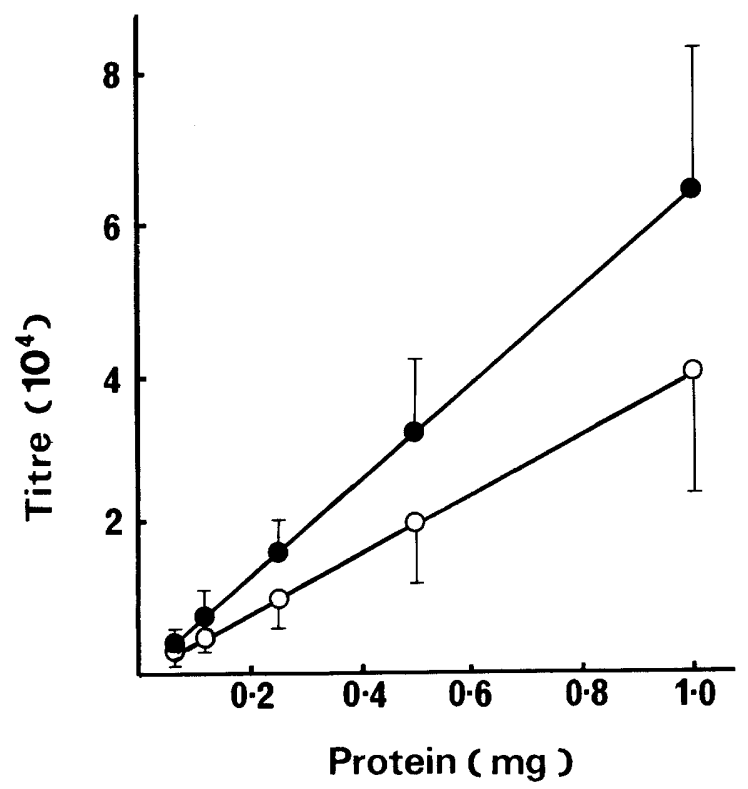

Fig. 5. Haemolysin $(O)$ and cytotoxin $(O)$ titres related to the amount of enterotoxic protein. Cytotoxin and haemolysin titres are means, with one SD of 4 (haemolysin) or 5 (cytotoxin) experiments.

$1 \mathrm{~h}$, whereas those that received $0 \cdot 25 \mu \mathrm{g}$ of the toxin survived for about $7 \mathrm{~h}$. The lethal activity was also inactivated by heating for $10 \mathrm{~min}$ at $56^{\circ} \mathrm{C}$.

The toxin did not react with antiserum to $\mathrm{CT}$ in ELISA. Ouchterlony immunodiffusion analysis showed lines of non-identity between CT and $A$. sobria cytotoxic enterotoxin with antisera to both toxins (fig. 7). None of the biological activities of the purified enterotoxin was neutralised by antiserum to CT.

\section{Discussion}

The purification and characterisation of toxins of Aeromonas spp. has been difficult because of the complexity of the extracellular protein profile of this species and instability of these toxins during classical techniques of biochemical purification (Ljungh and Wadstrom, 1982). Affinity chromatography with monoclonal antibodies is being used increasingly for the rapid and efficient purification of individual components from complex biological mixtures. With this technique we have purified an exotoxin of $A$. sobria and found it to be haemolytic, cytotoxic and enterotoxic, apparently properties of a single protein, in agreement with earlier reports (Hostacka et al., 1982; Asao et al., 1984).

The enterotoxin had an apparent mol. wt of c. 63000 , a pI of 6.2 and was homogeneous as determined by polyacrylamide gradient gel electrophoresis. Co-purification of enterotoxic, cytotoxic and haemolytic activities and the loss of these activities after incubation for $10 \mathrm{~min}$ at $56^{\circ} \mathrm{C}$ supported the view that the toxin was homogeneous. Immunological homogeneity was indicated by double immunodiffusion.

Biological activities in rat ileal loops, suckling mice, cell culture and haemolysin assay were similar to the properties of a haemolysin previously purified from a strain of $A$. hydrophila (Asao et al., 1984). Hostacka et al. (1982) also reported enterotoxic, cytotoxic and haemolytic activity from Aeromonas spp. in a fraction with mol. wt c. 60000 .

Similar to cytotoxic enterotoxin of Shigella dysenteriae and toxin $\mathrm{A}$ of Clostridium difficile (Gemmell, 1984), A. sobria cytotoxic enterotoxin causes fluid accumulation with damage to intestinal mucosa, induction of an inflammatory response and haemorrhage. Recently Thompson et al. (1984) reported that Bacillus cereus enterotoxin induces fluid accumulation in rabbit intestinal loops and is cytotoxic to Vero cells, haemolytic to rabbit erythrocytes and lethal to mice. Thus, haemolytic activity associated with enterotoxicity is not unique.

Although the suckling-mouse test is a technique routinely used for the detection of heat stable enterotoxins (STa's) produced by Escherichia coli, Klebsiella pneumoniae and Yersinia enterocolitica, we found, in agreement with other reports (Janossy and Tarjan, 1980; Burke et al., 1981; Johnson and 

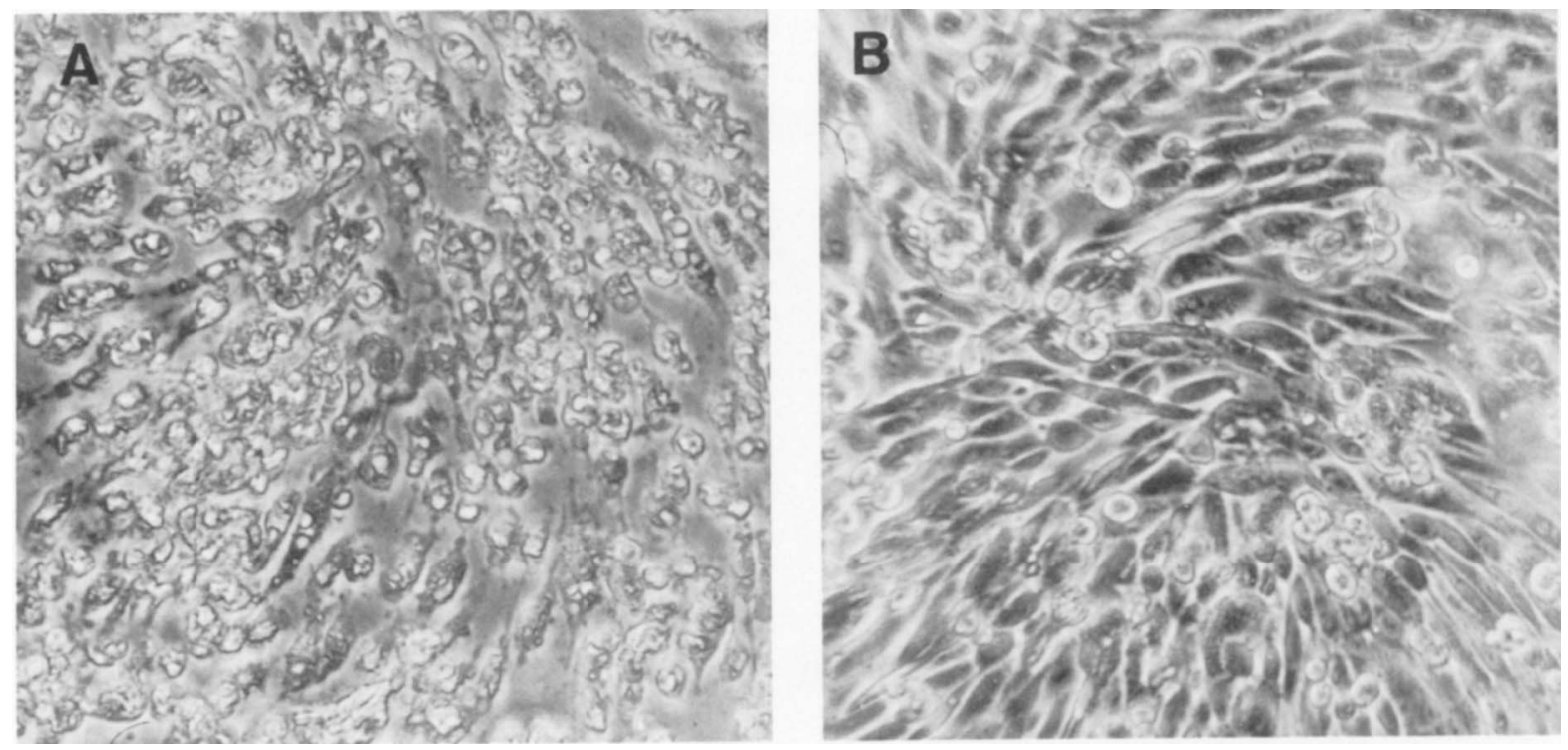

Fig. 6. Photomicrographs (phase contrast, unstained) of monolayer cultures of CHO cells. (A) Cells treated with toxin. (B) Untreated control cells (PBS).

Lior, 1981; Olivier et al., 1981; Turnbull et al., 1984), that $A$. sobria cytotoxic enterotoxin detected in the suckling-mouse test is heat labile. The $A$. sobria enterotoxin is not as potent as STa's; the minimum effective dosage of aeromonas cytotoxic enterotoxin in the suckling-mouse test was $130 \mathrm{ng}$ in comparison with $4.0 \mathrm{ng}, 5.9 \mathrm{ng}$ and $25 \mathrm{ng}$ of $E$.

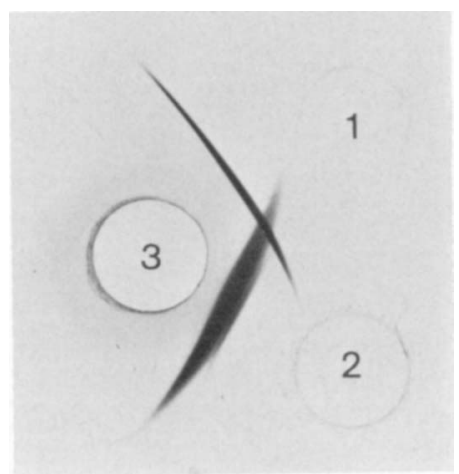

Fig. 7. Ouchterlony immunodiffusion analysis of the relationship of $A$. hydrophila toxin (1) to cholera toxin (2) with antisera to both toxins (3).

\section{REFERENCES}

Asao T, Kinoshita Y, Kozaki S, Uemura T, Sakaguchi G 1984 Purification and some properties of Aeromonas hydrophila hemolysin. Infection and Immunity 46: 122-127.

Burke V, Robinson J, Atkinson H M, Dibley M, Berry R J, Gracey M 1981 Exotoxins of Aeromonas hydrophila. Austra- coli, $K$. pneumoniae, $Y$. enterocolitica STa's, respectively (Klipstein et al., 1983; Inoue et al., 1983).

In our study the cytotoxic enterotoxin produced by the $A$. sobria strain did not cross-react with CT. There have been reports of immunological cross reactivity between cholera toxin (CT) or $E$. coli heat labile toxin (LT) and aeromonas enterotoxin (Dobrescu, 1978; James et al., 1982; Jiwa, 1983), not confirmed by other laboratories (Ljungh and Wadstrom, 1982). CT-like activity, detected in ELISA, has now been demonstrated to be produced by some strains of Aeromonas spp. (Shimada et al., 1984; Campbell and Houston, 1985).

Our results indicate that cross-reactivity with CT is not a characteristic of the purified cytotoxic enterotoxin of $A$. sobria but we have found that crude cell-free broth preparations of the same strain of $A$. sobria do cross react with CT in ELISA. These findings would be explained if this strain of $A$. sobria produced a CT-like enterotoxin in addition to the cytotoxic enterotoxin. We have now isolated this CT-cross reactive enterotoxin by affinity chromatography.

lian Journal of Experimental Biology and Medical Science 59 753-761.

Burke V, Robinson J, Berry R J, Gracey M 1981 Detection of enterotoxins of Aeromonas hydrophila with suckling-mouse test. Journal of Medical Microbiology $14:$ : 401-408.

Campbell J D, Houston C W 1985 Effect of cultural conditions on the presence of a cholera-toxin cross-reactive factor in 
culture filtrates of Aeromonas hydrophila. Current Microbi$\operatorname{ology} 12$ : 101-106.

Chakraborty T, Montenegro M. A, Sanyal S C, Helmuth R, Bulling E, Timmis K N 1984 Cloning of enterotoxin gene from Aeromonas hydrophila provides conclusive evidence of production of a cytotonic enterotoxin. Infection and Immunity 46 : 435-441.

Cumberbatch N, Gurwith M J, Langston C, Sack R B, Brunton J L 1979 Cytotoxic enterotoxin produced by Aeromonas hydrophila: relationship of toxigenic isolates to diarrheal disease. Infection and Immunity 23 : 829-837.

Dobrescu L 1978 Enterotoxigenic Aeromonas hydrophila from a case of piglet diarrhoea. Zentralblatt für Veterinarmedizin $B$ 25: 713-718.

Galfre G, Milstein C 1981 Preparation of monoclonal antibodies: strategies and procedures. Methods in Enzymology 73: 3-46.

Gemmell C G 1984 Comparative study of the nature and biological activities of bacterial enterotoxins. Journal of Medical Microbiology 17: 217-235.

Hostacka A, Ciznar I, Korych B, Karolcek J 1982 Toxic factors of Aeromonas hydrophila and Plesiomonas shigelloides. Zentralblatt für Bakteriologie, Mikrobiologie und Hygiene. 1 Abteilung Originale A 252: 525-534.

Inoue T, Okamoto K, Moriyama T, Takahashi T, Shimizu K, Miyama A 1983 Effect of Yersinia enterocolitica ST on cyclic guanosine $3^{\prime} 5^{\prime}$ monophosphate levels in mouse intestines and cultured cells. Microbiology and Immunology 27:159 166.

James C, Dibley M, Burke V, Robinson J, Gracey M 1982 Immunological cross-reactivity of enterotoxins of Aeromonas hydrophila and cholera toxin. Clinical and Experimental Immunology 47: 34-42.

Janossay G, Tarjan V 1980 Enterotoxigenicity of Aeromonas strains in suckling mice. Acta Microbiologica Academiae Scientiarum Hungaricae 27: 63-69.

Jiwa S F H 1983 Enterotoxigenicity, hemagglutination and cell surface hydrophobicity in Aeromonas hydrophila, Aeromonas sobria and Aeromonas salmonicida. Veterinary Microbiology 8: $17-34$.

Johnson W M, Lior H 1981 Cytoxicity and suckling mouse reactivity of Aeromonas hydrophila isolated from human sources. Canadian Journal of Microbiology 27: 1019-1027.

Klipstein F A, Engert R F, Houghten R A 1983 Immunological properties of purified Klebsiella pneumoniae heat-stable enterotoxin. Infection and Immunity 42: 838-841.

Ljungh A, Wadstrom T 1982 Aeromonas toxins. Pharmacology and Therapeutics $15: 339-354$.

Ljungh A, Wretlind B, Möllby R 1981 Separation and characterization of enterotoxin and two haemolysins from Aeromonas hydrophila. Acta Pathologica et Microbiologica Scandinavica. Section B 89: 387-397.

Margolis J, Kenrick K G 1968 Polyacrylamide gel electrophoresis in a continuous molecular sieve gradient. Analytical Biochemistry 25 : 347-362.

Okamoto K, Inoue T, Moriyama T, Miyama A 1983 Heat-stable enterotoxin produced by Yersinia enterocolitica. Toxicon 3: $325-328$.

Olivier G, Lallier R, Larivière S 1981 A toxigenic profile of Aeromonas hydrophila and Aeromonas sobria isolated from fish. Canadian Journal of Microbiology 27: 330-333.

Pierce N F 1977 Protection against challenge with Escherichia coli heat-labile enterotoxin by immunization of rats with cholera toxin/toxoid. Infection and Immunity 18: 338-341.

Popoff M 1984 Aeromonas Kluyver and Van Niel 1936 In: Krieg N R, Holt J G (eds) Bergey's Manual of systematic bacteriology vol. 1, 9th edn. Williams and Wilkins Co., Baltimore, pp 545-548.

Read S M, Northcote D H 1981 Minimization of variation in the response to different proteins of the Coomassie blue $\mathrm{G}$ dye-binding assay for protein. Analytical Biochemistry 116: 53-64.

Shimada T, Sakazaki R, Horigome K, Uesaka Y, Niwano K 1984 Production of cholera-like enterotoxin by Aeromonas hydrophila. Japanese Journal of Medical Science and Biology 37: 141-144.

Thompson N E, Ketterhagen M J, Bergdoll M S, Schantz E J 1984 Isolation and some properties of an enterotoxin produced by Bacillus cereus. Infection and Immunity 43 : 887894.

Turnbull P C B et al. 1984 Enterotoxin production in relation to taxonomic grouping and source of isolation of Aeromonas species. Journal of Clinical Microbiology 19: 175-180. 